\title{
Influence of Chess and Sudoku on Cognitive Abilities of Secondary School Students
}

\author{
Sijji Jose* and Remya Abraham \\ Department of M. Ed, Mangalam College of Education, Kottayam, Kerala-686632, India \\ *Email: sijjimanesh@gmail.com
}

\section{ARTICLE INFORMATION}

Received: September 28, 2018

Revised: November 13, 2018

Accepted: January 22, 2019

Published online: March 04, 2019

Keywords:

Brain Games-Chess and Sudoku, Cognitive abilities

\begin{abstract}
The concept of learning and education is undergoing a rapid change. Learning has to be an enjoyable experience for the learners. Learning can be converted into a fun filled activity. Here, comes the role of games in the learning situations in classrooms. Children of all age love playing games all the time. They will enjoy their learning experience if it is done through playing games. Games can be either physical or mental activities or both. The study is an attempt to find out the influence of Chess and Sudoku on cognitive abilities of school students of secondary level. The method chosen for the study is descriptive survey method. The sample for the study comprises of 350 students from various schools in Kottayam District. The statistical measures used for the study are mean, percentage, S.D, and t-test. It was found that Chess and Sudoku players scored high in cognitive abilities test than the non-players. Boys are more interested in playing Chess and Sudoku than girls. CBSE private schools have more players than Govt. aided schools. Also it was found that trained Chess players scored high in cognitive abilities test than the untrained players.
\end{abstract}

\section{Introduction}

Learning in the educational process means acquiring experiences. Experiences are acquired with the help of senses in human body, by seeing, hearing, touching, smelling and tasting-through these senses the brain absorbs certain knowledge of various sounds, images, tastes, feeling, emotions, fragrances, taste etc. Through such knowledge comes learning. Learning then brings about the real behavioural change mentally and physically. Learning need not happen only by reading books, listening to lectures or by doing experiments. Learning can takes place even while playing. Children love playing games. They enjoy all the activities while playing a game. Knowingly or unknowingly they learn a lot while playing games. There are different types of games, such as computer games, brain games, adventure games, puzzles, conversation games, etc.

Chess and Sudoku are two of the many brain games played commonly by school students. Chess requires cognitive abilities such as problem solving ability, planning, decision making, spatial ability, memory, concentration etc. Sudoku too requires abilities such as logical thinking, analysis, synthesis, and reasoning etc.
All these mental or cognitive abilities are very essential for effective learning in classrooms. Students should be encouraged to increase their cognitive abilities by playing such brain games in schools and at home.

\section{Need and Significance}

Today's education system is student-centered. It considers the likes and dislike of the student community. The system is trying to make learning a burdenless process. It is done by implementing policies such as reducing the weight of the bags of students, making the curriculum lighter and easy, avoiding too much of exams, replacing marking system with grading system to avoid unhealthy competitions, relieving small children from over burden of doing homework etc.

Teaching through games is one such strategy that is being implemented in schools to make learning an enjoyable experience. Games occupy a significant place in the life of a student. Games in a child's life, is one among the many sources that help him/her to grow into a matured personality. Games help in sharpening all the three domains namely the cognitive, affective 
and psychomotor domain. Games require skills like coordination, speed agility, endurance, dexterity, strength etc. Brain games require intelligences, grasping power, memory, attention, logic and reasoning, problem solving ability etc. Many of the subjects taught in schools also aim at improving such abilities and skills among students. So the investigator felt that there may be a connection between playing games especially the brain games and developing intellectual abilities such as memory, concentration, logic and reasoning, perception, problem solving etc. The practice of brain games may empower the cognitive skills required for achievements in subjects like mathematics, physics, chemistry, engineering etc. It is also noticed that, playing brain games and learning the science subjects in schools require almost the same set of cognitive skills. So it is felt that there may be an impact of playing brain games on the cognitive abilities of students.

\section{Review of Literature}

Bret C Laws (2014) conducted a study on the phenomena of abstract cognition among scholastic Chess participants. The study considers potentials such as social competency, academics, logical and visual and special competencies that benefit chess play. Playing chess engages students in an environment where the participant exercises optimum cognitive control in studying the Chess squares, thus allowing abstractness and cognition.

Sheila M (2014) conducted a study concerning the brain games and the effect it has on the memory and cognitive abilities. The objective of the study was to find out the effects of brain games on memory.

Sasa J (2015) conducted a study to find the influence of cognitive skills on the efficiency of basketball players. 48 basketball players were selected for conducting the study.

Sala, Pravettoni and Gorini (2015) conducted a study on Chess and mathematical abilities. Chess demands higher order cognitive abilities. The objective of the study was to find whether Chess playing can enhance the mathematical ability among children.

\section{Objectives of the Study}

- To find if there is a significant difference between the mean scores of the cognitive abilities of players and nonplayers of Chess and Sudoku at secondary school level.
- To find if there is a significant difference between the mean scores of the cognitive abilities of players of Chess and Sudoku at secondary school students based on gender and type of school.

- To find if there is a significant difference between the mean scores of the cognitive abilities of players and non-players of Chess and Sudoku among girls.

- To find if there is a significant difference between the mean scores of the cognitive abilities of players and non-players of Chess and Sudoku among boys

- To find if there is a significant difference between the mean scores of the cognitive abilities of players and non-players of Chess and Sudoku in government aided secondary schools.

- To find if there is a significant difference between the mean scores of the cognitive abilities of players and non-players of Chess and Sudoku in private CBSE secondary school.

- To find if there is a significant difference between the mean scores of the cognitive abilities among trained and untrained players of Chess.

\section{Hypotheses of the Study}

- There is significant difference between the mean scores of the cognitive abilities of players of Chess and Sudoku at secondary school level.

- There is significant difference between the mean scores of the cognitive abilities of players of Chess and Sudoku at secondary school students based on gender and type of school.

- There is significant difference between the mean scores of the cognitive abilities of players and non-players of Chess and Sudoku among girls.

- There is significant difference between the mean scores of the cognitive abilities of players and non-players of Chess and Sudoku among boys.

- There is significant difference between the mean scores of the cognitive abilities of players and non-players of Chess and Sudoku in government aided secondary schools.

- There is significant difference between the mean scores of the cognitive abilities of players and nonplayers of Chess and Sudoku in private CBSE secondary school.

- There is a significant difference between the mean scores of the cognitive abilities among trained and untrained players of Chess.

\section{Delimitation of the Study}

1. Time was a major constraint

2. Study was limited to Kottayam district only. 
3. Number of chess and Sudoku games players were very less

4. The present study was confined only to secondary school students

5. Limited sample size

6. Other brain games were not included

\section{Methodology}

\subsection{Population}

The population of the study taken in to consideration are the secondary school students of Kerala state.

\subsection{Sample taken for the study}

The sample taken comprises of 350 students studying in seventh, eighth, and ninth classes of government aided and private CBSE schools.

\subsection{Tools used for the study}

- Cognitive abilities test consisting of 30 items (developed and standardized by the investigator)

- Personal data sheet

\subsection{Statistical Measures}

- Percentage of scores of cognitive abilities

- Mean of the scores of cognitive abilities

- Standard deviation of the scores of cognitive abilities $\mathrm{t}$-test of means of scores of cognitive abilities

\section{Analysis and Interpretation}

\subsection{Preliminary Analysis}

- To find percentage of students playing Chess and Sudoku games at secondary level.

Table 1: Distribution of sample based on players and non-players

\begin{tabular}{|l|l|l|}
\hline Category & Number & Percentage \\
\hline Players & 162 & $47 \%$ \\
\hline Non-players & 188 & $53 \%$ \\
\hline Total & 350 & $100 \%$ \\
\hline
\end{tabular}

The Table 1 shows the percentage of players and nonplayers of chess and Sudoku games. It reveals that $47 \%$ of students playing Chess and Sudoku and 53\% of students do not play these games. Table 5.3 shows that majority of students are not playing Chess and Sudoku games.
- To find the percentage of boys and girls playing chess and Sudoku at secondary level.

Table 2: Distribution of sample based on gender.

\begin{tabular}{|l|l|l|l|}
\hline \multicolumn{2}{|l|}{ Category } & Numbers & Percentage \\
\hline \multirow{3}{*}{ Boys } & Players & 92 & $48.9 \%$ \\
\cline { 2 - 4 } & Non-players & 96 & $51.1 \%$ \\
\hline \multirow{2}{*}{ Girls } & Players & 70 & $43.2 \%$ \\
\cline { 2 - 4 } & Non-players & 92 & $56.8 \%$ \\
\hline
\end{tabular}

The Table 2 shows the percentage of boys and girls playing Chess and Sudoku at secondary level. 48.9\% of boys and $43.2 \%$ of girls play Chess and Sudoku at secondary school level. There are more players among boys (48.9\%) than girls (43.2\%) at secondary level. Among the boys at secondary level, there are $48.9 \%$ of players and $51.1 \%$ of non-players. Among the girls at secondary level, there are $43.2 \%$ of players and $56.8 \%$ of non-players.

Table 3: Distribution of players of Chess and Sudoku based on gender.

\begin{tabular}{|l|l|l|}
\hline Gender & Number & Percentage \\
\hline Boys & 92 & $56.79 \%$ \\
\hline Girls & 70 & $43.21 \%$ \\
\hline Total & 162 & $100 \%$ \\
\hline
\end{tabular}

The Table 3 reveals that of the total players of Chess and Sudoku, $56.79 \%$ are boys and only $43.21 \%$ are girls.

- To find the percentage of students playing Chess and Sudoku in Govt. aided and CBSE private Schools at Secondary level.

Table 4: Distribution of the sample based on type of school.

\begin{tabular}{|l|l|l|l|}
\hline \multicolumn{2}{|l|}{ Category } & Numbers & Percentage \\
\hline \multirow{2}{*}{ Govt. aided } & Players & 80 & $43 \%$ \\
\cline { 2 - 4 } & Non-players & 106 & $57 \%$ \\
\hline \multirow{2}{*}{ CBSE private } & Players & 82 & $50 \%$ \\
\cline { 2 - 4 } & Non-players & 82 & $50 \%$ \\
\hline
\end{tabular}

The Table 4 shows the percentage of students playing chess and Sudoku in Govt. aided and CBSE private schools at secondary level. The table reveals that there are 43\% players among students in Govt. aided schools and $50 \%$ players among students in CBSE private schools. There are more players in private CBSE schools than in Govt. aided schools. In Govt. aided schools, there are $43 \%$ players and $57 \%$ non-players. In private CBSE schools, there are $50 \%$ players and non-players. 
Table 5: Distribution of players of Chess and Sudoku based on type of school.

\begin{tabular}{|l|l|l|}
\hline Type of school & Number & Percentage \\
\hline Govt. aided & 80 & $49.4 \%$ \\
\hline CBSE private & 82 & $50.6 \%$ \\
\hline Total & 162 & $100 \%$ \\
\hline
\end{tabular}

Table 5 reveals that of the total players of Chess and Sudoku, $49.4 \%$ are from Govt. aided and 50.6\% are from CBSE private schools.

\subsection{Testing Hypotheses}

\section{Objective -1}

To determine if there is a significant difference in the mean scores of the cognitive abilities of players and nonplayers of Chess and Sudoku at secondary school level.

$\mathrm{H}_{0}$ : There is significant difference in the mean scores of the cognitive abilities of players of Chess and Sudoku at secondary school level.

Table 6: Result of the test of significant difference in the cognitive abilities scores of players and non-players of chess and Sudoku at the secondary level.

\begin{tabular}{|l|l|l|l|l|}
\hline Category & Mean & $\begin{array}{l}\text { Standard } \\
\text { deviation }\end{array}$ & z value & Comment \\
\hline Players & 20.65 & 2.77 & 5.068 & Significant \\
\hline Non-players & 10.33 & 2.62 & & \\
\hline
\end{tabular}

\section{Interpretation}

The calculated z-value is found to be 5.068 which is greater than 1.96 at $5 \%$ level of significance. There is a significant difference regarding the cognitive abilities of players and non players of Chess and Sudoku at the secondary level. Consequently, $\mathrm{H}_{0}$ is rejected.

\section{Objective -2}

To determine if there is a significant difference in the mean scores of the cognitive abilities of players of Chess and Sudoku at secondary school students based on gender wise.

$\mathrm{H}_{0}$ : There is significant difference in the mean scores of the cognitive abilities of players of Chess and Sudoku at secondary school students based on gender.

\section{Interpretation}

The calculated z-value is found to be 0.162 which is less than 1.96 at $5 \%$ level of significance. There is no significant difference regarding the cognitive abilities of player of Chess and Sudoku based on gender. Consequently, $\mathrm{H}_{0}$ is accepted.

\section{Objective- 3}

To determine if there is a significant difference in the mean scores of the cognitive abilities of players of Chess and Sudoku at secondary school students based on type of school.

$\mathrm{H}_{0}$ : There is significant difference in the mean scores of the cognitive abilities of players of Chess and Sudoku at secondary school students based on type of school.

Table 8: Result of test of significant in cognitive abilities of between the players of chess and Sudoku at the secondary school level based on type of school.

\begin{tabular}{|l|l|l|l|l|}
\hline Category & Mean & $\begin{array}{l}\text { Standard } \\
\text { deviation }\end{array}$ & z value & Comment \\
\hline $\begin{array}{c}\text { Govt. } \\
\text { aided }\end{array}$ & 20.30 & 2.60 & 0.109 & Not \\
\hline $\begin{array}{c}\text { CBSE } \\
\text { private }\end{array}$ & 21.01 & 2.89 & significant & \\
\hline
\end{tabular}

\section{Interpretation}

The calculated z-value is found to be 0.109 which is less than 1.96 at $5 \%$ level of significance. There is no significant difference regarding the cognitive abilities of player of Chess and Sudoku based on type of school. Consequently, $\mathrm{H}_{0}$ is accepted.

\section{Objective-4}

To determine if there is a significant difference in the mean scores of the cognitive abilities of players and non-players of Chess and Sudoku among girls.

$\mathrm{H}_{0}$ : There is significant difference in the mean scores of the cognitive abilities of players and nonplayers of Chess and Sudoku among girls.

Table 9: Result of test of significant difference in the cognitive abilities scores on cognitive abilities players and non-players of Chess and Sudoku among girls at the secondary level.

\begin{tabular}{|l|l|l|l|l|}
\hline Category & Mean & $\begin{array}{l}\text { Standard } \\
\text { deviation }\end{array}$ & z value & Comment \\
\hline Players & 19.83 & 2.28 & 2.88 & Significant \\
\hline $\begin{array}{l}\text { Non- } \\
\text { players }\end{array}$ & 8.97 & 1.99 & & \\
\hline
\end{tabular}

\section{Interpretation}

The calculated z-value is found to be 2.88 which is greater than 1.96 at $5 \%$ level of significance. There is 
a significant difference regarding the cognitive abilities of player and non-players of Chess and Sudoku among girls. Consequently, $\mathrm{H}_{0}$ is rejected.

\section{Objective-5}

To determine if there is a significant difference in the mean scores of the cognitive abilities of players and non-players of Chess and Sudoku among boys.

$\mathrm{H}_{0}$ : There is significant difference in the mean scores of the cognitive abilities of players and nonplayers of Chess and Sudoku among boys.

Table 10: Table showing the test result of significant difference regarding the scores of cognitive abilities of players and non-players of Chess and Sudoku among boys at secondary level.

\begin{tabular}{|l|l|l|l|l|}
\hline Category & Mean & $\begin{array}{l}\text { Standard } \\
\text { deviation }\end{array}$ & $\mathbf{z}$ value & Comment \\
\hline Players & 20.42 & 3.01 & 3.05 & Significant \\
\hline $\begin{array}{l}\text { Non- } \\
\text { players }\end{array}$ & 10.21 & 2.45 & & \\
\hline
\end{tabular}

\section{Interpretation}

The calculated z-value is found to be 3.05 which is greater than 1.96 at $5 \%$ level of significance. There is a significant difference regarding the cognitive abilities of player and non-players of Chess and Sudoku among boys. Consequently, $\mathrm{H}_{0}$ is rejected.

\section{Objective-6}

To determine if there is a significant difference in the mean scores of the cognitive abilities of players and non-players of Chess and Sudoku in government aided secondary schools.

$\mathrm{H}_{0}$ : There is significant difference in the mean scores of the cognitive abilities of players and nonplayers of Chess and Sudoku in government aided secondary schools.

Table 11: Table showing the test result of significant difference regarding the scores of cognitive abilities of players and non-players of Chess and Sudoku in government aided secondary schools.

\begin{tabular}{|l|l|l|l|l|}
\hline Category & Mean & $\begin{array}{l}\text { Standard } \\
\text { deviation }\end{array}$ & $\mathbf{z}$ value & Comment \\
\hline Players & 20.30 & 2.81 & 6.71 & Significant \\
\hline $\begin{array}{l}\text { Non- } \\
\text { players }\end{array}$ & 10.87 & 2.60 & & \\
\hline
\end{tabular}

\section{Interpretation}

The calculated z-value is found to be 6.71 which is greater than 1.96 at $5 \%$ level of significance. There is a significant difference regarding the cognitive abilities of player and non-players of Chess and Sudoku in government aided secondary schools. Consequently, $\mathrm{H}_{0}$ is rejected.

\section{Objective-7}

To determine if there is a significant difference in the mean scores of the cognitive abilities of players and non-players of Chess and Sudoku in private CBSE secondary school.

$\mathrm{H}_{0}$ : There is significant difference in the mean scores of the cognitive abilities of players and nonplayers of Chess and Sudoku in private CBSE secondary school.

Table 12: Table showing the test result of significant difference regarding the scores of cognitive abilities of players and non-players of Chess and Sudoku in private CBSE secondary school.

\begin{tabular}{|l|l|l|l|l|}
\hline Category & Mean & $\begin{array}{l}\text { Standard } \\
\text { deviation }\end{array}$ & z value & Comment \\
\hline Players & 21.01 & 2.89 & 8.74 & Significant \\
\hline $\begin{array}{l}\text { Non- } \\
\text { players }\end{array}$ & 9.66 & 2.20 & & \\
\hline
\end{tabular}

\section{Interpretation}

The calculated z-value is found to be 8.74 which is greater than 1.96 at $5 \%$ level of significance. There is a significant difference regarding the cognitive abilities of player and non-players of Chess and Sudoku in private CBSE secondary school. Consequently, $\mathrm{H}_{0}$ is rejected.

\section{Objective-8}

To determine if there is a significant difference in the mean scores of the cognitive abilities among trained and untrained players of Chess.

$\mathrm{H}_{0}$ : There is significant difference in the mean scores of the cognitive abilities among trained and untrained players of Chess.

Table 13: Result of test of significant difference in the scores of cognitive abilities among trained and untrained players of Chess at the secondary level.

\begin{tabular}{|l|l|l|l|l|}
\hline Category & Mean & $\begin{array}{l}\text { standard } \\
\text { deviation }\end{array}$ & z value & comment \\
\hline Trained & 22.13 & 2.45 & 9.74 & significant \\
\hline $\begin{array}{l}\text { Non- } \\
\text { players }\end{array}$ & 18.98 & 2.22 & & \\
\hline
\end{tabular}




\section{Interpretation}

The calculated z-value is found to be 9.74 which is greater than 1.96 at $5 \%$ level of significance. There is a significant difference regarding the cognitive abilities among the trained and untrained players of Chess. Consequently, $\mathrm{H}_{0}$ is rejected.

\section{Findings and Conclusion}

In the present study the investigator attempted to find out the influence of Chess and Sudoku on the cognitive abilities of secondary school students.

1. It was found that $47 \%$ students play Chess and Sudoku regularly and $53 \%$ students do not play such brain games.

2. $48.9 \%$ of the boys play Chess and Sudoku and $51.1 \%$ of the boys do not play such brain games.

3. Only $43.2 \%$ of the girls play Chess and Sudoku and $56.8 \%$ of the girls do not play these brain games.

4. Out of the total number of students who play Chess and Sudoku regularly, $56.79 \%$ are boys and $43.21 \%$ are girls.

5. In government aided schools, there are only $43 \%$ players and the rest $57 \%$ are non-players.

6. In CBSE private schools, half (50\%) of the total sample are players and the other half are non-players.

7. Among the total players of Chess and Sudoku, $49.4 \%$ are from Government aided schools and $50.6 \%$ are from CBSE private schools.

8. It is found that there is a significant difference ( $\mathrm{z}-$ value $=5.068)$ in the cognitive abilities between the players (mean value $=20.65)$ and non-players (mean value $=$ 10.33) of Chess and Sudoku.

9. There is no significant difference in the cognitive abilities of the players based on the gender $(z-$ value $=$ 0.162 ) and type of school ( $\mathrm{z}-$ value $=0.109$ ).

10. There is significant difference in the cognitive abilities of players (mean value $=19.83)$ and non-players $($ mean value $=8.97)$ of Chess and Sudoku among girls ( $\mathrm{z}-$ value $=2.88$ )

11. There is significant difference in the cognitive abilities of players (mean value $=20.42$ ) and non-players (mean value $=10.21)$ of Chess and Sudoku among boys ( $\mathrm{z}-$ value $=3.05$ )

12. There is significant difference in the cognitive abilities of players (mean value $=20.30$ ) and non-players (mean value $=10.87)$ of Chess and Sudoku in Government aided schools $(z$ - value $=6.71)$

13. There is significant difference in the cognitive abilities of players (mean value $=21.01)$ and non-players (mean value $=9.66)$ of Chess and Sudoku in CBSE private schools $(\mathrm{z}$ - value $=8.74)$
14. There is significant difference in the cognitive abilities of trained players (mean value $=22.13$ ) and untrained players $($ mean value $=18.98)$ of Chess $(\mathrm{z}$ - value $=9.74)$.

Thus, it is concluded that students who play brain games regularly are found to possess high levels of cognitive abilities compared to the ones who do not play brain games regularly. Also, training given to students for Chess is found to have a great impact on the development of cognitive abilities among players.

\section{Educational Implications of the Study}

1. Schools should provide time and facilities to encourage all the students to participate in such brain games, in order to develop the cognitive abilities of all the students.

2. More girls should be trained and encouraged to play such games.

3. Authorities of Govt. aided schools should pay more attention towards the participation of students in such brain games.

4. The school authorities should appoint good coaches or trainers for providing training to students for brain games.

5. Parents should encourage and enrol their wards into Academies that provide good Chess training programmes for school students.

\section{Future Directions}

1. Study can be conducted with more samples including the entire secondary schools in Kerala.

2. Similar studies can be conducted on other brain games.

3. The study is limited only to schools in Kottayam District. This can be extended further to other districts and states.

4. The study can be replicated in upper primary, higher secondary level and college level.

5. Study can be conducted using the independent variable 'Chess and Sudoku' on psychological variables such as confidence level, leadership quality, decision making ability and memory.

6. Study can be conducted using the independent variable 'Chess and Sudoku' and 'Academic achievement'.

7. Other brain games like Draughts, Rubric's cube, Lumosity, Happy Neuron, Cross word can be provided in school for the development of cognitive abilities in students.

8. Like other sports and arts items, schools can provide training facilities for such brain games.

9. Inter-class and inter-school competitions can be held occasionally in order to motivate the players and new participant. 


\section{References}

Best, J. W., \& Khan, J.V. (1983). Research in Education. New Delhi: Hall of India. Pvt Ltd, pp. 88-89.

Bhatia, K. K (2000). principles of education. New Delhi: Kalyani publications, p.56

Garret, H. (1971). Statistics in psychology and education. New York: David Mickey company, Bombay, p.337

Good Carter, V. (1972). Essentials of educational research. New York: Appleton century crafts Pvt Ltd, p.363.

Koul, Lokesh. (2005). Methodology of educational research. New Delhi: Vikas publishing house. Pvt Ltd, p.230.
Laws, C. (2014)." The phenomena of abstract cognition among scholastic chess participants: a case study". Electronic Thesis and Dissertations, pp 2458.

Mangal, S. K. (2008). Statistics in psychology and education. New Delhi: Prentice hall of India Pvt. Ltd, pp.330-335

Sasa, J. (2015). "The influence of certain cognitive abilities on situation efficiency of basketball players". pp.283-290. 13, no.2.2015>jakovljevic

Sheila, M (2014). "A study on the perception of brain games and their effect on memory and cognitive skills". Thesis of the University of Central Florida. 


\section{Issues and Ideas in Education}

Chitkara University, Saraswati Kendra, SCO 160-161, Sector 9-C, Chandigarh, 160009, India

Volume 7, Issue 1

March 2019

ISSN 2320-7655

Copyright: [C 2019 Sijji Jose and Remya Abraham] This is an Open Access article published in Issues and Ideas in Education (Issues Ideas Educ.) by Chitkara University Publications. It is published with a Creative Commons Attribution- CC-BY 4.0 International License. This license permits unrestricted use, distribution, and reproduction in any medium, provided the original author and source are credited. 